\title{
Contextual Learning Based on Multicultural Increase Students' Knowledge Competence in Civic Education
}

\author{
Ni Made Lyvia Komalasari Sudira1, I Komang Ngurah Wiyasa² \\ ${ }^{12}$ Primary School Teacher Education Study Program, Faculty of Education, Ganesha University of Education, Bali, Indonesia
}

\author{
A RTICLEINFO \\ Article history: \\ Received 2 Juni 2020 \\ Received in revised form \\ 12 Juli 2020 \\ Accepted 10 Agustus 2020 \\ Available online 28 Agustus \\ 2020 \\ kata kunci: \\ pembelajaran kontekstual, \\ multikultural, Civic \\ Education \\ keywords: \\ contextual learning, \\ multicultural, civic
}

\begin{abstract}
A B S T R A K
Civic Education yang belum dapat memberikan makna kepada siswa mengakibatkan perlu adanya inovasi dalam pembelajaran. Pembelajaran dapat diwujudkan dengan menerapkan pembelajaran kontekstual berbasis multikultural. Penelitian ini merupakan penelitian semu dengan nonequivalent control group design. Populasi pada penelitian ini berjumlah 130 siswa, sedangkan sampel pada penelitian ini berjumlah 44 siswa yang diambil menggunakan teknik Cluster Random Sampling. Pengumpulan pada penelitian ini instrumen tes objektif pilihan ganda sebanyak 32 soal. Berdasarkan analisis dengan uji-t polled varians diperoleh $t_{\text {hitung }}=3,83>t_{\text {tabel }}$ $=1,68$ pada taraf signifikansi $5 \%$ dengan $\mathrm{dk}=42$, yang berarti $\mathrm{H} 0$ ditolak dan Ha diterima. Hal ini membuktikan bahwa terdapat perbedaan yang signifikan kompetensi pengetahuan Civic Education antara kelompok siswa yang dibelajarkan dengan model pembelajaran Kontekstual berbasis Multikultural dengan siswa yang dibelajarkan dengan pembelajaran konvensional. Sehingga dapat disimpulkan bahwa pembelajaran Kontekstual berbasis Multikultural berpengaruh secara signifikan terhadap kompetensi
\end{abstract} pengetahuan Civic Education siswa SD. Implikasi pada penelitian ini adalah melalui penerapan pembelajaran Kontekstual berbasis Multikultural siswa dapat dengan mudah memaknai pembelajaran yang dilakukan.

\section{A B S T R A C T}

Civic education that has not been able to give meaning to students results in the need for innovation in learning. Learning can be realized by applying contextual learning based on multiculturalism. This research is a quasiresearch with nonequivalent control group design. The population in this study amounted to 130 students, while the sample in this study amounted to 44 students taken using the Cluster Random Sampling technique. The collection in this study was a multiple-choice objective test instrument of 32 questions. Based on the analysis of the polled variance $t$-test obtained $t$-count $=3.83>t$-table $=1.68$ at a significance level of $5 \%$ with $d k=42$, which means that $\mathrm{HO}$ is rejected and $\mathrm{Ha}$ is accepted. This proves that there are significant differences in the competence of civic knowledge between groups of students who are taught with the Multicultural Contextual learning model and students who are taught by conventional learning. So, it can be concluded that Multicultural-based Contextual learning has a significant effect on the civic knowledge competence of elementary students. The implication of this research is through the application of Multicultural-based Contextual learning students can easily interpret the learning that is done.

\section{Introduction}

The curriculum is used as a foundation for the implementation of education and the teacher is the spearhead, this is because the teacher is one of the important factors in the implementation of learning (Andari, I. A. K. M. L., 2019). Currently, Indonesia is implementing the 2013 Curriculum which uses an integrative thematic-based scientific approach which means combining various subjects in one theme. The integration of subjects in these learning activities is intended so that students do not realize they are studying certain subjects so that students are expected to understand a concept completely not only as knowledge but also applied through activities in learning(Lindayani, N. P. S., 2019).

One of the integrated subjects is Pancasila and Civic Education which aims to develop values, attitudes, and personalities in accordance with Pancasila (Wiyasa, I K. N., 2018). Pancasila and Civic Education in the 2013 curriculum is not merely a learning content but is one of the lessons that play a role in character building in accordance with Pancasila values (Miswandi, 2018). Character education becomes a hope for the formation of a moral generation (Sayektiningsih., 2017).

Copyright @ Universitas Pendidikan Ganesha. All rights reserved. 
Based on observations made on Tuesday, October 152019 at SD Gugus VII, South Kuta District, Badung Regency, the implementation of Civic Education learning is still dominated by the conventional system. The problem lies in the assumption that the Civic Education learning material is only memorizing and repetitive, this is reinforced by the implementation of learning that is still focused on textbooks which causes a lack of students' ability to build initial knowledge with the new ideas they learn. The values contained in Civic Education learning are important things that must be implemented. However, in practice, students still have difficulty connecting the learning they do with their daily lives, in this way it is difficult for students to gain learning experiences. By packaging learning activities that provide learning experiences for students will make learning meaningful (Muamanah, 2020).

As a step to create meaningful and beneficial learning for students, it is necessary to apply a learning model according to its function, namely to assist the teaching and learning process and providing information (Fitriasari, 2017). One learning model that can support this learning is Contextual Teaching and Learning (CTL) based on Multiculturalism.

Contextual Learning is learning that helps teachers as educators connect learning material with conditions faced by students in their daily lives so that it can help students connect the initial knowledge students have with their daily lives as members of the community so that the learning they do will become more meaningful. Contextual Learning is learning that involves students directly in connecting the material to be studied with real-world situations (Afriani, 2018). According to Aqib (2015), This learning will help students to create a link between the material being studied and its application in life. Contextual learning components, namely Constructivism, which helps students to build meaning from their experiences, find / inquiry which is a cycle of finding several knowledge and skills, asking is an activity that marks the process of observation into understanding, the Learning Community helps students to share experiences with students Another, Modeling that can be imitated by students, Reflection aims to identify things that are already known, and things that are not yet known so that an act of improvement can be taken, Authentic Assessment is a process of assessing both the knowledge and skills obtained by students from teachers and peers (Nilasari, E., 2018).

The difference between Contextual learning and learning that is usually carried out in elementary schools according to Aqib (2015) is that the material provided is in accordance with everything that is needed by students, students are directly involved in the learning that is carried out, simulating the relationship of the material taught with the daily life of students, The learning material provided is associated with students' prior knowledge, the learning carried out is more inclined to integrate various fields, student learning time is used more to practice critical thinking skills and being able to find solutions to problems both individually and in groups, student personalities are formed based on insightful attitudes. self, skills are constructed based on knowledge, good behavioral attitudes will lead to inner satisfaction, students do not violate the rules because they realize the consequences they will receive later, good attitudes and character are based on motivation from d Like the students themselves, learning can be carried out anywhere and under any circumstances, authentic assessment is used to measure the achievement of student mastery of the material. With the application of contextual learning, it will make students more active through learning that is linked to the real world of students so that the information provided is always associated with the knowledge that students already have and helps students build motivation from within themselves.

So that students' abilities can develop properly the application of Contextual learning in learning activities based on Multicultural-based learning. According to Banks (in Yanti,2018), Multicultural education is defined as a movement in education that aims to equalize all students from various backgrounds who have various backgrounds to get the same learning opportunities. Besides, multicultural education (multicultural education) can also be interpreted as learning that makes the cultural diversity of students to help build multicultural attitudes (Ngalimun, M., 2016). Multicultural education is suitable to be applied in learning in all mutant lessons in the 2013 curriculum (Wirasari, 2018). Through multicultural-based education, students can foster an attitude of tolerance for differences in the surrounding environment as a basis for building national insight. Through their tolerance, students will be able to carry out the right choices in dealing with problems in a narrow to a broader scope but still based on a rational perspective that is still based on the identity of their nation and country.

To be able to compile a multicultural-based Civic Education learning design, it can be done with five main stages according to Ngalimun (2016: 151), namely content analysis which is a process to determine the mapping of teaching materials, analysis of cultural backgrounds that come from 
cultural values that develop through the culture of the community in the surrounding environment and is useful for students, mapping learning material is related to determining the level of material to be taught to students, starting from simple material until students can analyze abstract concepts from a material, preparation of material to be taught to students in learning Multiculturalism must be based on the concept of what, who, where, when, why and how, then poured into a multiculturalbased learning model. In the implementation of multicultural learning, there are five stages according to (Ngalimun, 2016), namely, students identify socio-cultural problems in their surrounding environment related to the diversity that students will choose to learn the values contained therein, students explain the results of identification that have been done in front of other students, other group students responded to and commented on the results of the group students' exposure who presented the results of their analysis, the teacher responded to the results of the analysis presented by the students and the responses of other students, the teacher, and students reflected on the advantages of cultural values that had been discussed together and the benefits for life. society, nation, and state.

Theoretically, contextual learning has an effective impact on the success of a lesson. There are several relevant research results which reinforce that multicultural-based contextual learning has a positive impact on the success of student learning, among others Saputra (2017) which states that a contextual approach can affect student social studies learning outcomes but there are differences in the basis and content of learning, Sariani (2018) which states that the Tri Kaya Parisudha Oriented CTL learning model affects students' mathematics learning outcomes, the difference lies in the bases used and the learning content, and Bukhori (2018) which states that through planting multicultural values positively affects student behavior but the difference lies in the application of the model used and the learning carried out.

So this research was conducted to determine the effect of multicultural-based contextual learning on the competence of Civic Education knowledge for fifth-grade students of SD Gugus VII, South Kuta District, Badung Regency

\section{Research Method}

The implementation of this research was carried out in the even semester of the 2019/2020 school year. Regarding the implementation of the research starting from February 2020 to March 2020. The research implementation in each sample was carried out according to the schedule, curriculum, and syllabus that had been compiled so that it could provide treatment 6 times which was applied to the experimental and control groups. This type of research design is a quantitative study with experimental design, namely Quasi Experiment (Quasi Experiment).

In this design, there were two groups of subjects, namely the experimental group using Multicultural-based Contextual learning and the control group by applying conventional learning. Each group was given a pre-test to prove equality in the two groups, a post-test was carried out to determine the competence of students\&\#39; Civic Education knowledge seen from the value. After the two groups were declared equal, the determination of the experimental group and the control group was determined. After that, the researcher gave treatment to the experimental group by applying multicultural-based contextual learning. Then, a post-test was carried out to determine the competence of students\&\#39; Civic Education knowledge.

The stages of the implementation of this research consisted of three stages, namely the experimental preparation stage, the experiment implementation stage, the final stage of the experiment. In the experimental preparation stage, the first stage was an interview that was conducted with the head of cluster VII of South Kuta which aimed to determine students\&\#39; mastery of the learning content of Civic Education in general, after which the determination of the class to be sampled in the study was determined. To test the equivalence of existing research samples, a pre-test was carried out with research instruments that had been consulted with the homeroom teacher and supervisor. After the sample group was declared equal, a drawing was carried out to determine the experimental group and the control group. After that, preparations were made for the implementation of learning, namely the preparation of an RPP (Learning Implementation Plan) in consultation with the homeroom teacher. The experimental implementation stage began with giving a treatment by providing lesson plans Multicultural-based contextual to the experimental class and conventional learning lesson plans to the control class.

The treatment given was adjusted to the lessons available in the class and the treatment described was applied 6 times. After giving the treatment, a post-test was given which had previously been consulted with the homeroom teacher and the instrument test had been carried out. In the final 
stage of the research, the authors analyzed the data that had been obtained from the implementation of the post-test, then the results were used to test the hypotheses that had been determined in this study. In research, it is known as the population which is the subject in the study. In principle, the population is the whole object/subject member who is the target of the conclusion of the final results of a study. The population in this study were all fifth-grade students of SD Gugus VII, South Kuta District, Badung Regency, which consisted of 6 classes. The determination of the sample to be used cannot be randomized for each individual, this is because each student has been determined in a class that has been organized by the class teacher at the school. Conditions like this will make students not under the influence or condition that they are included in research activity. So that the effect of applying treatment to the sample is really visible.

The sampling method used in this research was Cluster Random Sampling, namely class random. The selection of the research sample group was not carried out by individual randomization but only class randomization. Before selecting the class to be sampled, a glass drawing was carried out, which contained a roll of paper with the name of the SD in Cluster VII South Kuta, after which the glass was shaken and then took two rolls of paper. To ensure that the two classes selected have relatively the same abilities, a pre-test is given so that in the calculation of the correct equivalence test it is known that the abilities of the two samples are relatively the same.

The data collected in this study are data about the knowledge competency of Civic Education in grade V SD Gugus, South Kuta District, Badung Regency which is the sample group. The data were obtained using the test method. According to Agung (2016), The test is a method of collecting data that is done by giving students a written test that the test taker does and produces a score. The test that will be used to measure the knowledge competence of Civic Education in this study is an objective test in the form of ordinary multiple choice. The multiple-choice test contains part of the information and several possible answers and correct answers (Arikunto, 2015). The data that has been obtained is then analyzed descriptively, which is an analysis used to analyze data by describing or describing the data that has been collected. If the data obtained has met the prerequisites for normality and homogeneity tests, the analysis is used in parametric statistics. The statistical analysis used to test the research hypothesis is the t-test. A hypothesis test was carried out using a t-test with the formula of polled variants.

\section{Result and Discussion}

The results of research that have been done by given each treatment 6 times in SD No. 4 Pecatu as an experimental group by applying a problem-based learning model assisted by project assessment and at SD No. 5 Pecatu as a control class applies conventional learning to obtain data on students' competency knowledge of Civic Education. The recapitulation of the results of post-test data analysis of the knowledge competence of Civic Education students in the experimental group and the control group is in Table 1.

Table 1. Summary of Descriptive Statistics of Knowledge Competencies for Civic Education

\begin{tabular}{ccc}
\hline Descriptive Statistic & Experiment Group & Control Group \\
\hline Mean & 83.85 & 74.58 \\
Variant & 76.24 & 55.99 \\
Standard Deviation & 8.73 & 7.48 \\
Maximum Score & 97 & 88 \\
Minimum Score & 69 & 63 \\
\hline
\end{tabular}

Based on the descriptive analysis of the knowledge competency data of the class $\mathrm{V}$ students of the experimental group with the highest score of 97 and the lowest score of 69 . From the data distribution, the mean (mean) was 83.85 , the variance was 79.24 and the standard deviation was 8.73. Whereas in the control group the highest score was 88 and the lowest score which is 63 . From the data distribution, the mean (mean) is 74.58 , the variance is 55.99 and the standard deviation is 7.48 .

The knowledge competency value data for Civic Education shows that groups that are taught through multicultural-based contextual learning have a higher average value than groups that are taught using conventional learning. Furthermore, hypothesis testing can be done. In testing the 
previous hypothesis, it must fulfill the prerequisite test analysis, including the normality test of data distribution and the homogeneity of variance. The recapitulation of the results of the normality test of the knowledge competency data distribution of the Civic Education in the experimental and control groups is presented in Table 2 as follows.

Table 2. Recapitulation of Normality Test Results for the Experimental Group and the Control Group

\begin{tabular}{ccccc}
\hline No. & Sample & $\begin{array}{c}\text { Maximum } \\
\text { Value I Ft-Fs I }\end{array}$ & $\begin{array}{c}\text { Value of Kolmogorov- } \\
\text { Smirnov }\end{array}$ & Information \\
\hline 1. & Experiment Group & 0,10 & & 0,29 \\
2. & Control Group & 0,10 & 0,27 & Normal \\
\hline
\end{tabular}

Based on the normality test of the experimental group, the maximum value was obtained at the maximum value of $\mid$ Ft-Fs $\mid=0.10$. Then the maximum value is compared with the KolmogorovSmirnov table value with a significance level of $5 \%(\alpha=0.05)=0.29$ and $N=20$ so that the comparison of the values $\mid$ Ft-Fs | <the Kolmogorov-Smirnov table value is $0.10<0.29$, meaning that the distribution of the experimental group data is normally distributed.

The results of the normality test of the control group, the data obtained from the normality test of the control group's maximum value of $|\mathrm{Ft}-\mathrm{Fs}|=0.10$ Then the maximum value is compared with the Kolmogorov-Smirnov table value at a significance level of $5 \%(\alpha=0.05)=0.27$ and $N=24$ so that the comparison of the maximum value $\mid$ Ft-Fs $\mid<$ the Kolmogorov-Smirnov table value is $0.10<0.27$, meaning that the control group is normally distributed.

The data in the experimental and control groups were normally distributed, so the homogeneity test was then carried out. The homogeneity test is intended to ensure that the differences in the t-test results obtained are true of the differences between groups. The homogeneity test of variance was carried out using the F test (fisher test). Through a significance level of $5 \%$ with degrees of freedom numerator $n_{1}-1$ as well as the degrees of freedom in the denominator $n_{2}-1$. With the provision that if F-count $>$ F-table then the sample is not homogeneous and if F-count $<$ Ftable then the sample is homogeneous. The summary of the results of the homogeneity test calculation in the study sample group is presented in Table 3 as follows.

Table 3 Recapitulation of Homogeneity Test of Research Sample Variances

\begin{tabular}{llccccc}
\hline No. & \multicolumn{1}{c}{ Sample } & Variant & DK & F-count & F-table & Information \\
\hline 1. & Experiment Group & 76,24 & 19 & 1,36 & 2,06 & Homogenous \\
2. & Control Group & 55,99 & 23 & & & \\
\hline
\end{tabular}

Based on the calculation of the results of the homogeneity test, the value of F-count $=1.36$. The value of F-table at 5\% significance level with the numerator dk n1 - 1 (24-1=23) and dk denominator $\mathrm{n} 2-1(20-1=19)$ is 1.74 so that the ratio F-count $<$ F-table is obtained so that testing the experimental and control group data obtained a homogeneous variance. Based on the prerequisite test, the experimental and control group data results were normally distributed and had homogeneous variance. The data collection has met the prerequisite test analysis so that it can perform hypothesis testing using parametric statistical analysis with polled variance t-test. The recapitulation of the t-test results in the two sample groups is presented in Table 4. as follows.

Table 4. Recapitulation of the Research Sample T-Test

\begin{tabular}{llccccccc}
\hline No. & \multicolumn{1}{c}{ Sample } & $\mathbf{N}$ & $\mathbf{D K}$ & Average & Variant & $\mathbf{T}_{\text {-count }}$ & T$_{\text {-table }}$ & Conclusion \\
\hline 1. & Experiment & 20 & & 83,85 & 76,24 & & & \\
& Group & & 42 & & & & \\
2. & Control Group & 24 & & 74,58 & 55,99 & & & $\mathrm{H}_{0}$ rejected \\
\hline
\end{tabular}

Based on the t-test data, namely $\mathrm{T}$-count $=3.83$ and the $\mathrm{T}$-table value through the $5 \%$ significance level and $\mathrm{dk}=\mathrm{n} 1+\mathrm{n} 2-2=20+24=42$, it shows that the T-table value is 1.68 . So that the results obtained from the analysis of the value of $t=3.83>t$ table $=1.68$, it is stated that $\mathrm{H} 0$ is rejected. This shows that there is a significant difference in the knowledge competence of Civic 
Education between the experimental group and the control group in class V SD VII, South Kuta District, Badung Regency, 2019/2020 academic year. The average value of the experimental group using multicultural-based contextual learning is $=82.85$ and students who take conventional learning are 74.58. The difference in knowledge competency that has been normalized, the mean of the experimental group is higher than that of the control group. These results are because the knowledge that students acquire using conventional learning models tends to come from remembering explanations in books and from teachers. Not all students have a good memory, so learning cannot last long in the minds of students, and students easily forget it. This does not reflect the implementation of Civic Education learning which requires learning strategies that can provide students with problem-solving abilities (Dewi, 2019). Through contextual learning that is carried out, students' cognitive abilities develop more optimally, because multicultural-based contextual learning can involve students directly and actively in finding and discovering the concept of learning material (Lider, 2018). Furthermore, the application of multicultural-based learning brings students to appreciate and be able to get along with anyone regardless of cultural background (Feli, 2019), in line with it Pradana (2018) said that multicultural education has an important role in developing the cognitive, psychomotor, and affective domains of students which can have a major effect on the understanding of the learning material being carried out. Good student understanding will certainly influence the knowledge competence of Civic Education.

When the learning process took place which was carried out in the experimental group, it was seen that the students were very enthusiastic about the learning being carried out. Students look easy to understand the lesson because students only follow the instructions given by the teacher and students implement them. When students are asked questions related to the material, students can immediately find out the answer because the material being studied is related to the realities that exist in their daily lives. Sefudin and Berdiati (in Aprelia, D. A., 2019) reveal the concept of learning that can help a teacher in connecting the knowledge that students have with the application in their life, namely contextual learning. The knowledge gained will be meaningful if students learn it by presenting it through the context of student life, so that it will be fun for students (Tilaar, 2019). There are three basic concepts in contextual learning, namely, 1) the learning process carried out by students is not only based on receiving information, but students are asked to search and find their subject matter. 2) students are asked to find a relationship between the material being studied and real-life situations so that students can correlate the material they get with real life, so the learning material is not only functional but will be embedded in the students' memory. 3) students are not only required to understand the learning material but students are also required to implement it in their daily life (Hamruni, 2015). This makes students not easily forget the material they are learning. Leighbody \& Kidds stated that the skills of students or students doing something over and over again can become automatic habits so that students do not easily forget what they are learning (in Nurtanto \& Sofyan, 2015). Setiawan, P \& Sudana (2019) stated that the importance of learning is a strategy, how students understand the meaning of learning, how benefits can students receive, and how students can achieve it. And to create these conditions, students need a contextual approach, because students are not required to memorize facts but, students are encouraged to construct their knowledge. The results of this study are also strengthened by the results of other studies conducted by Susila (2013) which states that there is a significant influence between the contextual learning approach and the conventional learning approach on student Civics learning outcomes, with the calculation result that is FA $=21.29<\alpha=\mathrm{m}$ 0.05. In research conducted by Suarjana, I. M., et., al., (2017) revealed that the learning outcomes in cycle II, namely using a contextual approach assisted by concrete media, increased to $78.57 \%$ from the first cycle that did not use a contextual approach assisted by concrete media. In a study conducted by Putra (2017), the application of the contextual learning model can solve mathematical problems assisted by Hands-On Activity (HoA) which affects the ability to solve mathematical problems. However, what distinguishes the research conducted by Susila (2013) and this research is that this research more specifically proves whether there is a significant effect of the application of multicultural-based contextual learning on the knowledge competency of Civic Education, while Susila (2013) measures the effect of the application of contextual learning in terms of interest to learn. What distinguishes this research from research conducted by Suarjana, I. M., et., al., (2017) is the use of a multicultural base in learning while research conducted by Suarjana, I. M., et., al., (2017) assisted by concrete media. In research Putra (2017) examines the ability to solve mathematical problems and in this study examines the competence of knowledge of Civic Education and multicultural based learning. Based on this explanation, it can be concluded that Multicultural-based Contextual learning affects the knowledge competence of Civic Education in class V SD Gugus VII, South Kuta District, Badung Regency. 


\section{Conclusion}

Based on the results of the analysis and discussion, it is found that there is a significant difference in the knowledge competence of Civic Education between groups of students who are taught with a Multicultural-based Contextual learning model and students who are taught using conventional learning. So it can be concluded that Multicultural-based Contextual learning has a significant effect on the knowledge competence of Civic Education for fifth-grade students of SD Gugus VII Kuta Selatan Badung. Based on the results of research, discussion and conclusions, several recommendations can be submitted, namely teachers in elementary schools can apply Multiculturalbased Contextual learning by preparing material and adapting it to learning syntax to increase students' competence in Civic Education knowledge, To the Principal through research results which are obtained can be used as material for policies in improving the quality of Civic Education learning carried out by teachers and can facilitate all student learning activities. To be able to make the results of this research as study material in making a policy that can have a better influence on Civic Education learning, to other researchers who want to examine contextual learning models or other learning models that have identical characteristics with Contextual learning so that this research can be used references and studies that are relevant and can support the research being carried out. And to other researchers so that they can be used as references or relevant research.

\section{References}

Afriani, A. (2018). Pembelajaran Kontekstual (Contextual Teaching and Learning) dan Pemahaman Konsep Siswa. Jurnal Al-Muta'aliyah STAI Darul Kamal NW Kembang Kerang. http://ejournal.kopertais4.or.id/sasambo/index.php/mutaaliyah/article/view/3005

Agung, A. A. G. (2016). Statistika Dasar untuk Pendidikan. Yogyakarta: Deepublish.

Andari, I. A. K. M. L., dkk. (2019). Pengaruh Model Problem Based Learning (PBL) Berbasis Portofolio Terhadap Hasil Belajar IPS. International Journal of Elementary Education, 3 (4). http://dx.doi.org/10.23887/ijee.v3i4.21309

Aprelia, D. A., dkk. (2019). Pengaruh Pendekatan Kontekstual Dalam Meningkatkan Keterampilan Menulis Narasi. Mimbar PGSD Undiksha, 7. http://dx.doi.org/10.23887/jipgsd.v7i3.19400

Aqib, Z. (2015). Model-Model, Media, dan Strategi Pembelajaran Kontekstual (inovatif). Bandung: Yrama Widya.

Arikunto, S. (2015). Dasar-Dasar Evaluasi Pendidikan. Jakarta: Bumi Aksara.

Bukhori, I. (2018). Metode Penanaman Nilai-Nilai Multikultural Pada Siswa Kelas Rendah (Studi Pada Mi Di Mwcnu Lp. Jurnal Pendidikan Agama Islam, 2. https://doi.org/10.33650/edureligia.v2i1.756

Dewi, M. A. C. (2019). Pengaruh Model Quantum Teaching Berbasis Tri Hita Karana Terhadap Kompetensi Pengetahuan Civic Education Siswa Kelas V. Jurnal Pendidikan Multikultural Indonesia, 2. http://dx.doi.org/10.23887/jpmu.v2i1.20790

Feli, N. F. (2019). Implementasi Multicultural Based Learning Dalam Meningkatkan Prestasi Siswa. Jurnal MUDARRISUNA, 9. http://dx.doi.org/10.22373/im.v9i1.4469

Fitriasari, S. (2017). Model Pembelajaran Pendidikan Pancasila dan Kewarganegaraan untuk Menumbuhkan Karakter Peduli Lingkungan Hidup Siswa. Prosiding Konferensi Nasional Kewarganegaraan III. http://eprints.uad.ac.id/9777/1/167175\%20Susan\%20Fitriasari1\%2C\%20Riyan\%20Yudistira.pdf

Hamruni. (2015). Konsep Dasar dan Implementasi Pembelajaran Kontekstual. Institutional Repository UIN SUNAN KALIJAGA YOGYAKARTA, 12. https://doi.org/10.14421/ipai.2015.122$\underline{04}$

Lider, G. (2018). Pengaruh Pendekatan Pembelajaran Kontekstual Bermuatan Nilai Budaya dan Karakter Bangsa terhadap Hasil Belajar Ditinjau dari Sikap Demokrasi Pendidik. Indonesian Values and Character Education Journal, 1. http://dx.doi.org/10.23887/ivcej.v1i1.20301

Lindayani, N. P. S., dkk. (2019). Pengaruh Model Pembelajaran Value Clrification Technique Bermuatan Nilai Karakter Terhadap Kompetensi Pengetahuan Civic Education. Thinking Skills 
and Creativity Journal, 2. http://dx.doi.org/10.23887/tscj.v2i2.20709

Miswandi. (2018). Peningkatan Hasil Belajar PKN SD melalui Stategi Crossword Puzzle. JURNAL PENDIDIKAN: Riset \& KonseptuaL, 2. https://doi.org/10.28926/riset konseptual.v2i3.66.

Muamanah, H. (2020). Pelaksanaan Teori Belajar Bermakna David Ausubel Dalam Pembelajaran $\begin{array}{lllll}\text { Pendidikan Agama Islam. Jurnal Pendidikan } & \text { Islam, } 5 .\end{array}$ http://dx.doi.org/10.29240/belajea.v5i1.1329

Ngalimun, M., dkk. (2016). Strategi dan Model Pembelajaran. Yogyakarta: Aswaja Pressindo.

Nilasari, E., dkk. (2018). Pembelajaran Tematik Berbasis Kontekstual Di Sd Muhammadiyah 9 Malang. Jurnal Teori dan Praksis Pembelajaran IPS. Jurnal Teori Dan Praksis Pembelajaran IPS, 3. 10.17977/um022v3i12018p019

Nurtanto \& Sofyan. (2015). Implementasi Problem-Based Learning untuk Meningkatkan Hasil Belajar Kognitif, Psikomotor, dan Afektif Siswa di SMK. Jurnal Pendidikan Vokasi, 5. https://doi.org/10.21831/jpv.v5i3.6489

Pradana, R. W. B. (2018). Menumbuhkan Karakter Peserta Didik melalui Pendidikan Multikultural Pada Pembelajaran Seni Budaya. Proceedings of The ICECRS, 1. https://doi.org/10.21070/picecrs.v1i3.1384

Putra, F. G. (2017). Eksperimentasi Pendekatan Kontekstual Berbantuan Hands On Activity (HoA) Terhadap Kemampuan Pemecahan Masalah Matematik. Al-Jabar: Jurnal Pendidikan Matematika, 8 (1). https://doi.org/10.24042/ajpm.v8i1.1148

Saputra, W. D. (2017). Pengaruh Pendekatan Kontekstual Terhadap Hasil Belajar IPS Siswa Kelas V SD Negeri 1 Gondangrejo. Tugas Akhir Skripsi. Jurusan Ilmu Pendidikan, Universitas Lampung. http://dx.doi.org/10.23960/jpp

Sariani, N. L. A. (2018). Pengaruh Model Pembelajaran CTL Berorientasi Tri Kaya Parisudha Terhadap Hasil Belajar Matematika Siswa Kelas III. Journal of Education Technology, 2, 95-102. http://dx.doi.org/10.23887/jet.v2i3.16372

Sayektiningsih., dkk. (2017). Penanaman Nilai-Nilai Karakter Dalam Pembelajaran Pendidikan Pancasila Dan Kewarganegaraan. Jurnal Managemen Pendidikan, 12.10.23917/imp.v12i3.5518

Setiawan, P \& Sudana, I. D. N. (2019). Penerapan Model Pembelajaran Kontekstual Untuk Meningkatkan Hasil Belajar Matematika. Jurnal Ilmiah Pendidikan Profesi Guru, 2. http://dx.doi.org/10.23887/jippg.v1i2.16397

Suarjana, I. M., dkk. (2017). Penerapan Pendekatan Kontekstual Berbantuan Media Konkret Untuk Meningkatkan Aktivitas dan Hasil Belajar. International Journal of Elementary Education. http://dx.doi.org/10.23887/ijee.v1i2.11601

Susila, dkk. (2013). Pengaruh Pendekatan Pembelajaran Kontekstual Terhadap Hasil Belajar PKn Ditinjau Dari Minat Belajar Siswa. E-Journal Program Pasca Sarjana Universitas Pendidikan Ganesha, 3. https://media.neliti.com/media/publications/119774-ID-pengaruh-pendekatanpembelajaran-konteks.pdf

Tilaar, A. L. (2019). Efektivitas Pembelajaran Kontekstual dalam Mengajarkan Matematika. Jurnal Formatif, 1, 186-191. http://dx.doi.org/10.30998/formatif.v1i3.72

Wirasari, dkk. (2018). Pengaruh Pelaksanaan Pendidikan Multikultural Pada Mata Pelajaran Sejarah Terhadap Sikap Pluralis Siswa Kelas XI SMA Negeri 2 Pekalongan Tahun Pelajaran 2017/2018. Indonesian Journal of History 6. https://journal.unnes.ac.id/sju/index.php/ijhe/article/view/27356

Wiyasa, I K. N., dkk. (2018). Pengaruh Model Pembelajaran Open Ended Berbasis Penilaian Proyek Terhadap Kompetensi Pengetahuan Civic Education Siswa. Jurnal Ilmiah Pendidikan Dan Pembelajaran. http://dx.doi.org/10.23887/jipp.v2i2.15407

Yanti, R. P. (2018). Pembelajaran Berbasis Multikultural pada Mata Pelajaran Sosiologi. Padang: Universitas Negeri Padang, 2. https://media.neliti.com/media/publications/278073pembelajaran-berbasis-multikultural-pada-c11159b9.pdf 